\title{
SUBTERRANEAN CACHING OF DOMESTIC COW (BOS TAURUS) CARCASSES BY AMERICAN BADGERS (TAXIDEA TAXUS) IN THE GREAT BASIN DESERT, UTAH
}

\author{
Ethan H. Frehner1,3, Evan R. Buechley ${ }^{1}$, Tara Christensen¹, and Çağan H. Şekercioğlu1,2
}

\begin{abstract}
Camera traps documented 2 solitary American badgers (Taxidea taxus) independently caching juvenile domestic cow (Bos taurus) carcasses during late winter 2016 in the Great Basin Desert of Utah. One carcass was partially buried and the other was entirely buried. Both badgers constructed dens alongside their cache, where they slept, fed, and spent up to 11 days continuously underground. They abandoned the sites 41 and 52 days after initial discovery. While badgers are known to scavenge and to cache small food items underground, this is the first evidence of an American badger caching an animal carcass larger than itself.
\end{abstract}

Resumen.-Cámaras de caza grabaron a dos independientes y solitarios Tejónes Americanos (Taxidea taxus) almacenando cadáveres de becerro (Bos taurus) a finales del invierno del 2016 en el Desierto del Gran Barreño (Great Basin) de Utah. Uno de los cadáveres de becerro fue enterrado parcialmente mientras que el otro fue completamente enterrado. Ambos tejònes construyeron madrigueras junto a su almacén, donde durmieron, comieron y pasaron once días continuos bajo tierra. Después de este descubrimiento inicial los dos abandonaron sus escondites después de 41 y 52 días. Aunque a los tejònes les conocen por buscar carroña y almacenar alimentos pequeños bajo la tierra, esta es la primera evidencia de un tejón Americano almacenando el cadáver de un animal más grande que el mismo.

The American badger (Taxidea taxus) is a midsize fossorial mustelid that ranges throughout western and central North America from northern Alberta, Canada, to central Mexico. It measures 600 to $730 \mathrm{~mm}$ in total length (Long 1978) with females weighing an average of $6.3 \mathrm{~kg}$ and males an average of $8.6 \mathrm{~kg}$ (Lindzey 2003). Badgers are generalist carnivores, whose diets are composed of a wide variety of nutrient sources including carrion and occasional plant material, although their morphological adaptations make them especially adept at excavating underground for small burrowing mammals, which make up the majority of their diet (Jense and Linder 1970, Lindzey 1971, Messick and Hornocker 1981, Goodrich and Buskirk 1998).

Badger morphology is specialized to facilitate scratch-digging and subterranean excavation. Thick protective fur and a conical head equipped with nictitating eyelids, along with stout, heavily muscled forelimbs and long front claws (Moore et al. 2013) facilitate underground hunting and den making. Badgers also use this suite of evolutionary adaptations to their advantage by caching the carcasses of small mammalian prey, including ground squirrels and jackrabbits, in holes and dirt mounds (Snead and Hendrickson 1942, Lindzey 1971, Michener 2000). Subterranean caching of carrion has been thought to primarily be a strategy to supplement fresh kills and prevent discovery and pilferage of excess food by vertebrate scavengers (Michener 2000, Hüner and Peter 2012) and invertebrates, and to also slow the rate of microbial decomposition through temperature regulation in a cooler underground microclimate (Bischoff-Mattson and Mattson 2009, Inman et al. 2012).

Here we report 2 independent occurrences of American badgers burying carcasses of large animals (domestic cattle) in the Great Basin desert of western Utah during the late winter and early spring of 2016. These events, recorded in detail using camera traps, are the first documentation of this behavior by the American badger.

\section{Methods}

In a study of scavenger ecology in the Great Basin Desert, 7 domestic calf (Bos taurus) carcasses were placed on public land managed

\footnotetext{
${ }^{1}$ Biodiversity and Conservation Ecology Lab, University of Utah, 257 S. 1400 E., Salt Lake City, UT 84112

${ }^{2}$ College of Sciences, Koç University, Rumelifeneri, Istanbul 34450, Turkey.

${ }^{3}$ E-mail: ehfrehner@gmail.com
} 
TABLE 1. Site locations (decimal degrees) and elevations.

\begin{tabular}{lccc}
\hline Site & Latitude & Longitude & Elevation $(\mathrm{m})$ \\
\hline 1 & 40.891248 & -112.951609 & 1320 \\
2 & 40.827532 & -112.995248 & 1447 \\
3 & 40.872537 & -113.051194 & 1433 \\
4 & 40.758076 & -113.090869 & 1304 \\
5 & 40.867862 & -113.113961 & 1297 \\
6 & 40.845341 & -113.032534 & 1409 \\
7 & 40.894412 & -113.000178 & 1372 \\
\hline
\end{tabular}

by the Bureau of Land Management (BLM) in northwestern Utah. The carcasses were acquired from a local dairy farm in Richfield, Utah. The calves had died from natural causes either during birth or soon after, and were kept frozen until they were placed out for the study. The carcasses weighed between 18.6 and $26.9 \mathrm{~kg}(\bar{x}=22.9 \mathrm{~kg})$. The carcasses were placed at least $3 \mathrm{~km}$ apart (Table 1) in habitat that included sparse Utah juniper (Juniperus osteosperma) on higher and hillier sites, greasewood (Sarcobatus vermiculatus) in bottoms, and widely distributed cheatgrass (Bromus tectorum). The soil in the study area is composed of loose to moderately compacted limnological sediments, including gravels and clays. The carcasses were fixed to a concealed stake in the ground so as to prevent scavengers from dragging off the complete carcass. The carcasses were monitored with Bushnell Trophy Cam HD motion-activated cameras. The cameras were all programmed to take 1 photo when triggered, with a 10-s delay between subsequent photos (the delay is to reduce having multiple photos of the same animal visitation event). The sites were visited every 2 weeks to check equipment and download camera data.

Photos were entered into CameraBase Version 1.7 (Tobler 2007), a camera-trap photo management platform in Microsoft Access. Each photo was viewed to check for the presence of any vertebrates, which were identified to species. All photos containing badgers were examined to compare the pelage patterns of dorsal head stripes and differentiate between individuals as described by Harrison (2016). Because all cameras were programmed to take 1 picture when triggered, with a 10-s delay, the total number of photos of each species can be used as a standardized metric of animal presence at a carcass (Hamel et al. 2013).

\section{Results}

Badger activity was observed at 4 of the 7 carcass sites: Sites 1, 2, 3, and 6. At Sites 1 and 2 , activity was limited to investigation of the carcass and feeding behavior lasting no more than 2 min. At Site 3, a badger partially buried the carcass, and the carcass at Site 6 was buried entirely (Supplementary Material 1). Both badgers dug burrows alongside the carcasses in which they fed and slept.

The carcasses at both of these sites were placed on 11 January 2016. At Site 3, the badger discovered the carcass on 13 January (Fig. 1). At Site 6, the badger discovered the carcass on 16 January (Fig. 2). Sites 3 and 6 were located $3.4 \mathrm{~km}$ apart, and the badgers were photographed near simultaneously at the 2 different sites. Furthermore, inspection of pelage patterns showed no evidence that more than a single solitary badger visited each of the 2 sites through the duration of the study. Both badgers inspected the carcasses and the surrounding area for $<2 \mathrm{~min}$ on their first visit. They each exhibited their first feeding behavior the day following initial discovery, tearing at the underbelly and the back of the carcasses, respectively.

At Site 3, the badger returned intermittently to feed on the carcass over the course of several days following its discovery, tearing a large opening in the carcass's lower abdomen and feeding on internal organs. This behavior occurred from 15 January through 17 January, at which point the badger was first seen digging around the carcass in an episode that lasted from 14:06 to 14:15. After this point, the badger began to return twice daily to dig for 10-20 min at a time-once in the early morning between 01:00 and 03:00, and once between 11:00 and 12:30. The badger would stop occasionally during these episodes to feed upon the carcass. This pattern continued until 19 January, when a portion of the badger's subterranean excavation collapsed, causing the hindquarters of the carcass to fall into the badger's hole.

On 21 January, the badger at Site 3 began residing in a den that it had constructed alongside the carcass, after which point it spent the majority of its time underground until 17 February. During this time, the badger rarely left the immediate vicinity of the partially buried carcass, emerging from the hole only to 


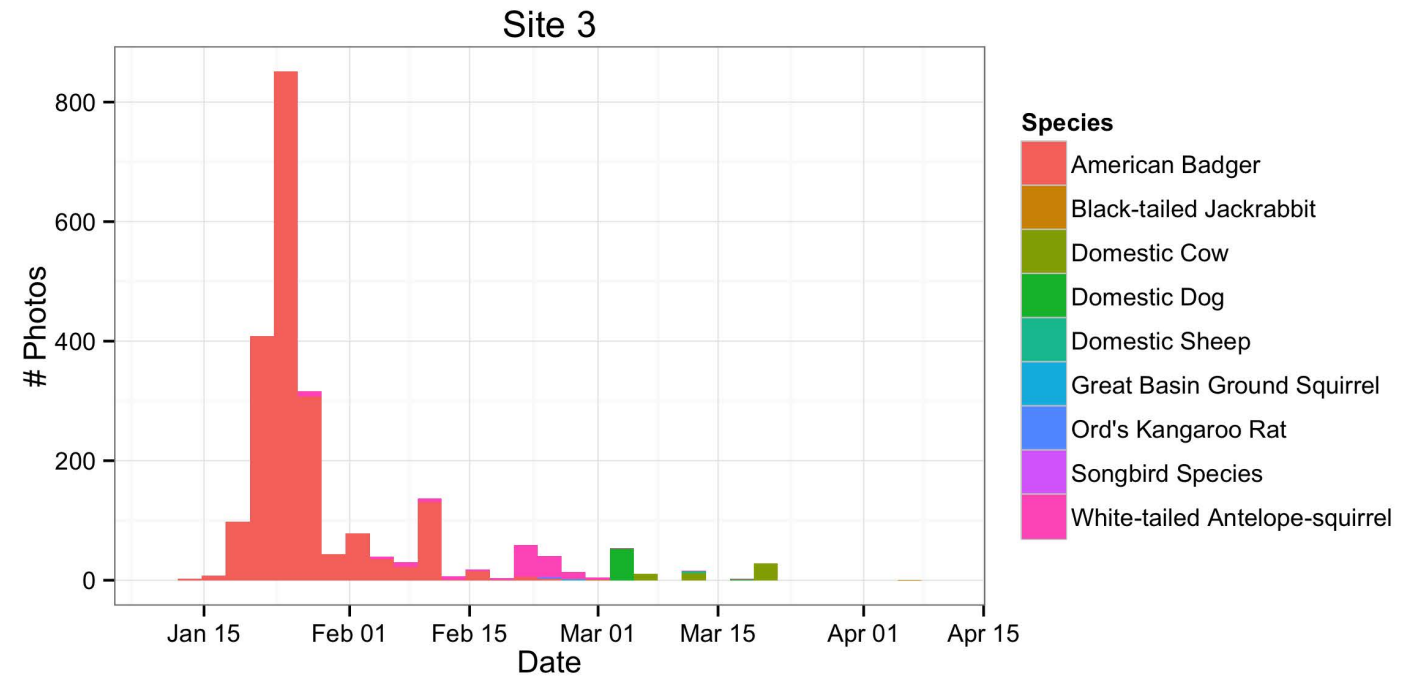

Fig. 1. Vertebrate camera-trap photograph captures at Site 3.

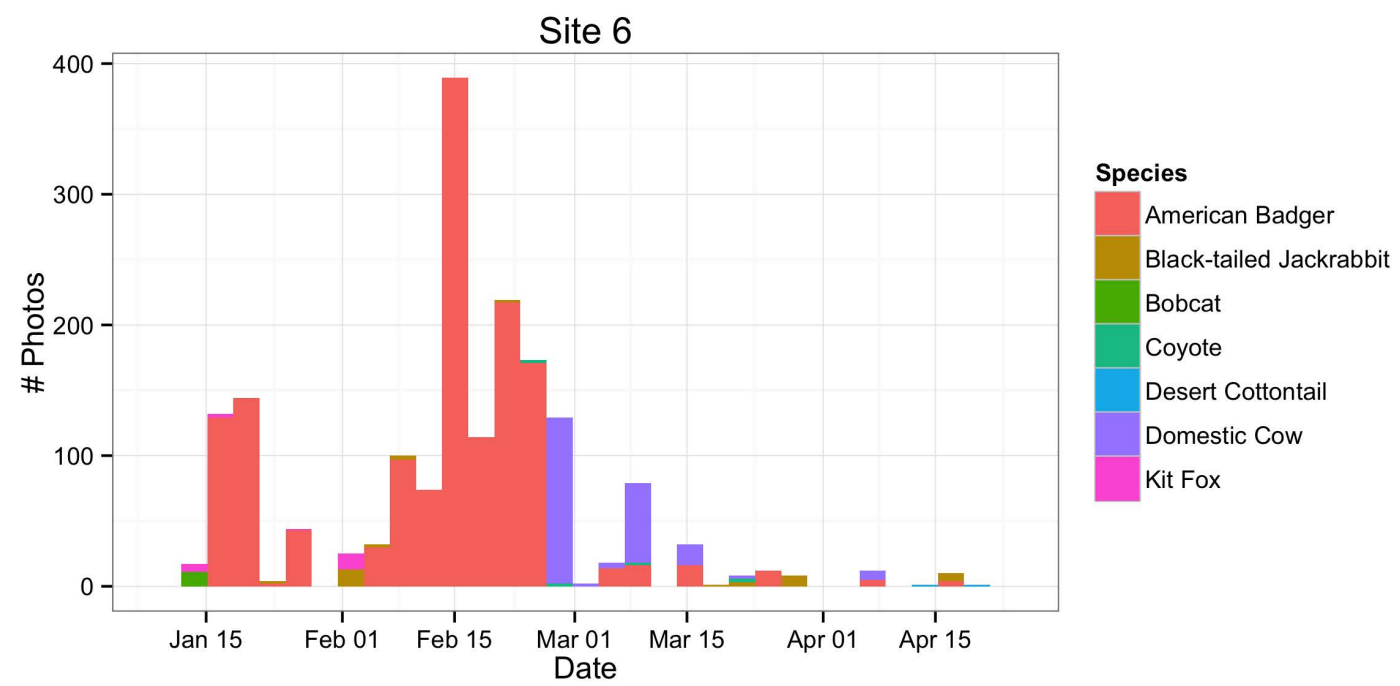

Fig. 2. Vertebrate camera-trap photograph captures at Site 6. The arrival of domestic cows appears to have caused the badger to abandon its den site at the carcass.

inspect the area around the entrance of the burrow and attempt to maneuver the carcass the rest of the way into its hole-though the anchoring stake prevented the badger from ever accomplishing this. On 28 January and 5 February, the badger did not emerge from its burrow at all, staying underground for $28 \mathrm{~h}$ and $33 \mathrm{~h}$, respectively. On the morning of 7 February, the badger left the burrow and did not return for $72 \mathrm{~h}$, and even then only stopped for $13 \mathrm{~min}$ to feed at the entrance of the burrow. The badger returned twice more for visits lasting no more than $10 \mathrm{~min}$ on 16 February and 21 February, and was not seen again after that.

The badger at Site 6 invested a considerable effort in burying the carcass in the days immediately following its initial discovery on 16 January. It excavated below and around the carcass from 18:03 to 22:24 on 17 January, with only a single pause to feed, which lasted for $5 \mathrm{~min}$. It resumed digging the following 


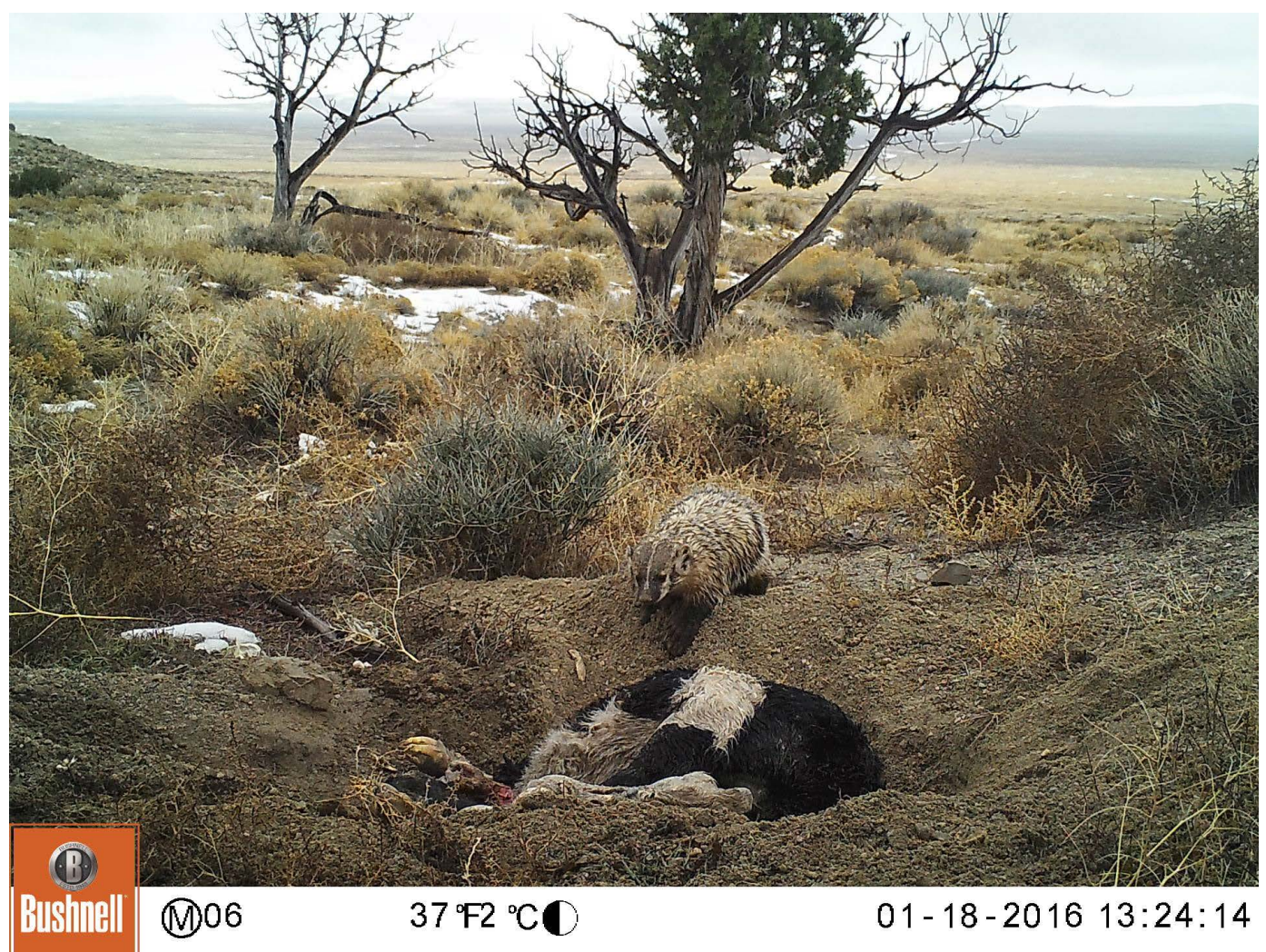

Fig. 3. An American badger (Taxidea taxus) actively burying a juvenile domestic cow (Bos taurus) carcass at Site 6 in the Great Basin Desert of northwestern Utah.

afternoon, 18 January, at 13:10, and by 13:24 a tunnel had collapsed, bringing the entire carcass down with it and leaving the carcass approximately half submerged (Fig. 3). The badger continued to dig until 16:15, by which time the carcass had fallen further down into what was at that point a substantial hole measuring approximately $70 \mathrm{~cm}$ deep and nearly $2 \mathrm{~m}$ in diameter. The badger then made an effort to partially cover the carcass with dirt and left shortly thereafter at 16:19.

When the badger returned at 9:55 on the morning of 19 January, there had been another collapse within the excavation that left a crater into which the carcass had completely disappeared. After this point, the badger spent the majority of its time in or around the hole, leaving the immediate vicinity of the carcass only sporadically and for increasingly short amounts of time. The badger instead put its time into backfilling over the carcass and leveling the ground where it had been, leaving only a small entrance to its subterranean cache. By 21 January, the badger had appeared to fully move into a burrow next to the carcass, and until 6 February, it spent the majority of its time underground. It came to the entrance for approximately $2 \mathrm{~min}$ on 23 January and left the site for $3 \mathrm{~h}$ on 25 January and $5 \mathrm{~h}$ on 6 February.

On 7 February, the badger emerged from its hole at 11:02, covered the entrance to its hole with dirt, and left the site. It didn't return until the following night, 8 February, at 20:18, at which point it uncovered the entrance and reentered the hole. It reemerged the morning of 9 February at 11:59, reburied the entrance, left the site, and returned that afternoon at 14:45. From this point on, until 25 February, the badger spent the majority of its time in the burrow or rolling around in the dirt immediately outside of the entrance. It made only occasional trips off-site, covering the entrance before 
leaving for anything more than half an hour at a time.

On 25 February, the badger left the site at 13:51. A herd of domestic cows came into the area later that day at 20:55, and they occupied the site until 17:27 on 29 February. There were no photos of them at the site after 29 February and no photos of the badger returning until 4 March. Following its return, the badger spent most of the next 2 days in the burrow, but after cows again passed by the site at 12:30 and 15:04 on 6 March, the badger appeared agitated, repeatedly entering and exiting the den and pacing in circles around its entrance. On 8 March, the badger left the site, leaving its den for the last time. Over the next 3 months there was substantial cattle activity at and around Site 6, and though a badger made visits of no more than $10 \mathrm{~min}$ to the site on 16 March and 24 March, and 7 April and 16 April, it never reentered the burrow.

During the study, the badgers at both Site 3 and Site 6 were active during all hours of the day, though both had a peak in their activity levels in the middle of the day between 10:00 and 13:00. This is somewhat surprising, considering the species' typically nocturnal habits. Once the badgers had established themselves at these sites, observed activity of other species decreased substantially compared to the other 5 sites in the study. At Site 3, there were only occasional visitations of the site by whitetailed antelope squirrels (Ammospermophilus leucurus) during the badger's presence, with the rodents approaching the mouth of the burrow in order to retrieve fur from the carcass (presumably to be used as nesting material). At Site 6 there were photographs of passing black-tailed jackrabbits (Lepus californicus) and brief investigative visits by a solitary bobcat (Lynx rufus), kit fox (Vulpes macrotis), and coyote (Canis latrans) prior to the arrival of domestic cows at the site, which appears to have caused the badger to abandon its burrow.

\section{Discussion}

To our knowledge, this is the first documented account of an American badger-or any other mustelid-burying an immovable carcass significantly more massive (3-4 times) than itself. Several North American mustelid species, including the wolverine (Gulo gulo), marten (Martes americana), and long-tailed weasel (Mustela frenata) have been known to cache carcasses of ungulates and rodents (Henry et al. 1990, Muths 1998, Inman et al. 2012), and a study by Hüner and Peter (2012) described a fisher (Martes pennanti) caching an American black bear (Ursus americanus) carcass in situ beneath branches and bracken (but not burying it). Though American badgers have previously been documented feeding on large mammalian carrion, such as domestic pig (Sus scrofa domesticus) and cattle (Bos taurus) (Snead and Hendrickson 1942, Sovada et al. 1999), there have been no previously published records of badgers caching items larger than jackrabbits (Snead and Hendrickson 1942, Lindzey 1971, Michener 2000).

American badger activity in this study has demonstrated that badgers are capable of caching carcasses weighing over $20 \mathrm{~kg}$; they would thus likely be able to bury the majority of carrion items that they encounter in the wild. This is ecologically significant as American badgers are widespread mammals that could be responsible for consuming a much larger portion of carrion in many ecosystems than previously thought, potentially having a significant impact on nutrient cycling across their large geographic range. Furthermore, the burial of diseased carcasses could provide a significant ecosystem service to ranchers.

\section{Supplementary Material}

One online-only supplementary file accompanies this article (scholarsarchive.byu.edu/ wnan/vol77/iss1/13).

Supplementary Material 1 . Time-lapse video of Site 6, showing a solitary badger completely burying the carcass of a juvenile cow.

\section{ACKNOWLEDGMENTS}

The National Science Foundation generously supported this project in the form of a Graduate Research Fellowship to E.R. Buechley. Field methods were approved by the University of Utah Institutional Animal Care and Use Committee. We thank the Bureau of Land Management for permission to conduct this study on public land, Brown Rex Dairy for donating calf carcasses, and undergraduate students at the University of Utah who assisted in all aspects of this project, especially 
Ethan Slocum, Hector Castillo, Miranda Castillo, and Dylan Harding.

\section{Literature Cited}

Bischoff-Mattson, Z., AND D. MatTson. 2009. Effects of simulated mountain lion caching on decomposition of ungulate carcasses. Western North American Naturalist 69:343-350.

GoOdrich, J.M., AND S.W. Buskirk. 1998. Spacing and ecology of North American badgers (Taxidea taxus) in a prairie-dog (Cynomys leucurus) complex. Journal of Mammalogy 79:171-179.

Hamel, S., S.T. Killengreen, J.A. Henden, N.E. Eide, L. Roed-Eriksen, R.A. Ims, and N.G. Yoccoz. 2013. Towards good practice guidance in using cameratraps in ecology: influence of sampling design on validity of ecological inferences. Methods in Ecology and Evolution 4:105-113.

HARRISON, R.L. 2016. Noninvasive identification of individual badgers by features of their dorsal head stripes. Western North American Naturalist 76:259-261.

Henry, S.E., M.G. Raphael, and L.F. Ruggiero. 1990. Food caching and handling by marten. Great Basin Naturalist 50:381-383

HÜner, E.A., AND J.F.B. Peter. 2012. In situ caching of a large mammal carcass by a fisher, Martes pennanti. Canadian Field-Naturalist 126:234-237.

Inman, R.M., A.J. Magoun, J. Persson, and J. Mattisson. 2012. The wolverine's niche: linking reproductive chronology, caching, competition, and climate. Journal of Mammalogy 93:634-644.

JENSE, G.K., AND R.L. Linder. 1970. Food habits of badgers in eastern South Dakota. Proceedings of the South Dakota Academy of Science 49:37-41.

LinDzeY, F.G. 1971. Ecology of badgers in Curlew Valley, Utah and Idaho with emphasis on movement and activity patterns. Master's thesis, Utah State University, Logan, UT.

Lindzey, F.G. 2003. Badger. Pages 683-691 in G.A. Feldhamer, B.C. Thompson, and J.A. Chapman, editors, Wild mammals of North America. 2nd edition. Johns Hopkins University Press, Baltimore, MD.

LONG, C.A. 1978. Taxidea taxus. Mammalian Species 26: $1-4$.

Messick, J.P., and M.G. Hornocker. 1981. Ecology of the badger in southwestern Idaho. Wildlife Monographs 76:1-53.

Michener, G.R. 2000. Caching of Richardson's ground squirrels by North American badgers. Journal of Mammalogy 81:1106-1117.

Moore, A.L., J.E. Budny, A.P. Russell, And M.T. Butcher. 2013. Architectural specialization of the intrinsic thoracic limb musculature of the American badger (Taxidea taxus). Journal of Morphology 274:35-48.

Muths, E. 1998. An observation on caching of prey by a long-tailed weasel (Mustela frenata). Southwestern Naturalist 43:106.

Snead, E., and G.O. Hendrickson. 1942. Food habits of the badger in Iowa. Journal of Mammalogy 23: 380-391.

Sovada, M.A., J.M. Roaldson, and A.B. Sargeant. 1999. Foods of American badgers in west-central Minnesota and southeastern North Dakota during the duck nesting season. American Midland Naturalist 142:410-414.

Tobler, M.W. 2007. Camera Base, version 1.3. Botanical Research Institute of Texas. http://www.atrium-bio diversity.org/tools/camerabase

Received 5 August 2016

Accepted 9 January 2017

Published online 31 March 2017 